\title{
EL POETA ERNESTO LÓPEZ-PARRA EXCOMULGADO DEL ULTRAÍSMO
}

\author{
PABLO ROJAS \\ I.E.S. Alonso de Orozco \\ Oropesa (Toledo)
}

Para Alfonso Diezma Jiménez.

\section{RESUMEN}

El ultraísmo español quiso superar al modernismo precedente. Muchos poetas ultraístas procedían de él, y eso se aprecia en sus composiciones. El ultraísmo, como el futurismo, era poco complaciente con la tradición. Sin embargo, no faltaron ultraístas heterodoxos: Gerardo Diego, por ejemplo, no despreció la voz del pasado. Tampoco Ernesto López-Parra. Ambos colaboran en Vltra, una revista nacida para depurar al ultraísmo de elementos vacilantes. El estreno de Paisaje de abanico provoca la expulsión de López-Parra de sus páginas. Este gesto enlaza el ultraísmo con parecidas actitudes sectarias propias de la vanguardia internacional. La desaparición de Vltra marca el fin del movimiento. Tras ella nacen revistas más plurales paradójicamente promocionadas por los vanguardistas más ortodoxos.

Palabras clave: Ultraísmo, Gerardo Diego, Ernesto López-Parra, Vltra, expulsión

\section{THE POET ERNESTO LÓPEZ-PARRA EXCOMMUNICATED FROM THE ULTRAÍSMO MOVEMENT}

\begin{abstract}
Spanish Ultraism had as a main goal to leave behind Modernism. Many poets that take part in that movement had been previously modernists, and that infects many of their poems. Ultraism, like Futurism, hates tradition. In spite of all that there are some heterodox ultraists: Gerardo Diego, for example, didn't repudiate the past. Neither does Ernesto López-Parra. Both collaborate in Vltra, a magazine which tries to purge Ultraism of indecisive writers. The release of Paisaje de abanico provokes the expulsion of Lopez-Parra from its pages. That gesture relates Spanish Ultraism with International avant-garde. The end of Vltra is the end of Ultraism. After that, new and more plural magazines appear, promoted in many occasions by all those who were especially fierce in the persecution of dilettante poets.
\end{abstract}

Key words: Ultraism, Gerardo Diego, Ernesto López-Parra, Vltra, expulsion. 
Los distintos movimientos de vanguardia surgidos en Europa en los primeros decenios del siglo XX se caracterizaron por su abierto espíritu rupturista. El futurismo, el creacionismo, el dadaísmo, el ultraísmo o el surrealismo no pretendieron edificar sobre lo existente sino que volcaron sus esfuerzos en el descubrimiento de nuevos caminos que ayudaran a oxigenar a la viciada escena literaria de su tiempo. En unos casos — dadaísmo, creacionismo, surrealismo - el enemigo a batir era el realismo y la fuente filosófica de la que manaba: el racio-positivismo decimonónico; en otros casos —ultraísmo- lo que se pretendía era algo mucho más localista y perentorio como dar carpetazo a las viejas y manidas fórmulas modernistas; finalmente, el futurismo fue quizá la corriente vanguardista más osada en sus objetivos al partir de una actitud adánica que condenaba al olvido a todo el arte precedente. Todos estos movimientos nacen de la fuerza renovadora de personajes visionarios como F. T. Marinetti, Vicente Huidobro, André Breton o Tristan Tzara, quienes se sirven de manifiestos, poemas, proclamas o textos doctrinales para desglosar sus ideas. Estos autores se convierten así en ejes vertebradores de un nutrido grupo de artistas que rápidamente deciden adherirse a sus postulados. El caso del ultraísmo es, sin embargo, bien distinto. Para empezar porque su primer manifiesto no nace del ingenio de un renovador como pudiera ser Marinetti sino que viene firmado por siete personas, carentes de obra reconocida, y a las que parecía aglutinar una común coincidencia: su amistad con Rafael Cansinos Assens. El grueso de esos firmantes (César A. Comet, Xavier Bóveda, J. Rivas Panedas, etc) lo constituían miembros habituales de la tertulia que Cansinos mantenía en el madrileño café Colonial, como no deja de anotar el autor sevillano en su libro de memorias La novela de un literato. Guillermo de Torre, por su parte, confesó años después que su firma había sido añadida sin su autorización. El ultraísmo nacía de este modo descabezado, entre otras razones porque, como es de sobra conocido, se trataba de un movimiento híbrido que bebía de las teorizaciones vanguardistas llegadas a España desde Francia y desde Italia. El futurismo, el creacionismo, el cubismo o dadá eran así algunas de sus fuentes caudales. Los redactores del manifiesto eran plenamente conscientes de su falta de originalidad y ponían un único límite a los poetas dispuestos a sumarse a su empresa: que sus creaciones estuvieran alentadas por un ferviente deseo de novedad: «Nuestro lema será «Ultra», y en nuestro credo cabrán todas las tendencias, sin distinción, con tal que expresen un anhelo nuevo» ${ }^{1}$. Paradójicamente la mayor parte de los jóvenes poetas que se subían al carro del ultra provenían del modernismo, escuela que tratarán de abandonar a la carrera pero que dejará indeseadas salpicaduras en sus

\footnotetext{
1 «Ultra. Un manifiesto de la juventud literaria». Esta proclama apareció en la prensa madrileña en otoño de 1918. Entre otros lugares, se recoge en BRIHUEGA, Jaime. Manifiestos, proclamas, panfletos y textos doctrinales. Las vanguardias artísticas en España 19101931. Madrid: Cátedra (Cuadernos Arte, 8), 1979, p. 102; y en ROTA, Ivana. I manifesti dell'ultraismo spagnolo, Viareggio, Lucca, Mauro Baroni editore, 2002, p. 96.
} 
poemas de nuevo cuño. De este tipo de híbridos están llenas las revistas que acogen las primeras muestras de poesía ultraísta: Los Quijotes, Cervantes, Grecia.

Los poetas que de la noche a la mañana se pasan al ultraísmo elevan a Rafael Cansinos Assens a la categoría de líder del grupo. De hecho en ese primer manifiesto los firmantes le atribuyen un papel fundacional y prometen continuar su labor «de acuerdo con la orientación señalada por Cansinos-Asséns en la interviú que en diciembre último con él tuvo X. Bóveda en «El Parlamentario» (...)» $»^{2}$. Lo cierto es que el autor de El divino fracaso procedía, como el resto de poetas ultraístas, de aquello que ahora se pretendía superar: el novecentismo. Así se hacía constar en el manifiesto y así lo subraya Guillermo de Torre: «Insistiré, no obstante (...) que Cansinos-Asséns fue el primero que, en el momento de la definición ultraísta, se alzó indirectamente contra los valores de su generación -que poco antes había exaltado- mostrando su senectud cumplida e incitando a los jóvenes a la busca de otros modelos, al hallazgo de sí mismos» ${ }^{3}$.

Cansinos, igual que Guillermo de Torre, estaba atento a las novedades que llegaban de Europa, en particular de Francia, y cooperará en la labor de abrir los ojos a los jóvenes creadores. Pedro Garfias, por ejemplo, así lo manifiesta en uno de sus primeros y titubeantes poemas ultraístas:

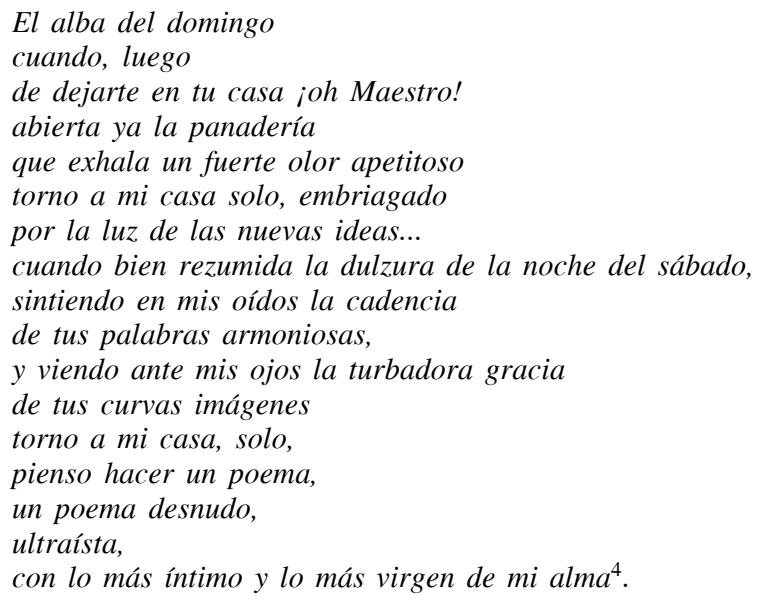

Cansinos, un poco a su pesar, o al menos con cierta displicencia, se convierte de la noche a la mañana en guía espiritual de lo que tiene visos de llegar a convertirse en una especie de nueva religión. Véanse si no las palabras

\footnotetext{
${ }^{2}$ Idem.

${ }^{3}$ TORRE, Guillermo de. Historia de las literaturas de vanguardia, II. Madrid: Ediciones Guadarrama 1971, p. 196. Col. Punto Omega, 118.

${ }^{4}$ «A Rafael Cansinos-Asséns». Grecia, 1 de abril de 1919, n. ${ }^{\circ}$ 12, p. 8.
} 
que su rendido admirador Isaac del Vando-Villar le tributa con motivo de la edición de su libro El divino fracaso:

En «El Divino Fracaso» se inicia la curva prodigiosa de «Ultraísmo» donde seguramente con el prestigio de su magia nos llevará a todos sus discípulos para iniciarnos en el Nuevo Arte del cual Cansinos es Gran Sacerdote y está revestido litúrgicamente con su mitra azul y bien ceñida su alba por el cíngulo lírico de los grandes martirios $(\ldots)^{5}$.

Cansinos es así el «Maestro», el «Sacerdote», el «Gran Maestre» o el «Apóstol» del Ultra, apelativos que se le prodigan por revistas como Grecia, Cervantes o Los Quijotes. Es importante destacar esa retórica próxima a la religión que los ultraístas asumen para sí, porque, como después veremos, al movimiento no le serán ajenas otras manifestaciones mucho más expeditivas de lo sacro como pueden ser las excomuniones. El propio Cansinos, pese a todo, rebajará el alcance de su participación en la experiencia vanguardista, y en sus memorias, cuando alguien se le acerca motejándole de «Padre» del ultraísmo, le aclara: «—iSu padre! —sonrío—. Yo soy solamente su padrino... Cualquiera sabe quién es su padre... ¡Son tantos los que se disputan esa paternidad!...» ${ }^{6}$

El principal competidor de Cansinos en esa paternidad es Guillermo de Torre, quien tampoco aporta novedad teórica alguna, pues su trabajo consiste fundamentalmente en poner a disposición de los escritores españoles las directrices estéticas que se mueven por Europa. De Torre se refiere al papel de Cansinos en el ultra en su libro de 1925 Literaturas europeas de vanguardia, y allí apunta: «La significación, el papel de Cansinos en los albores ultraicos ha sido el de un promotor teórico, el de un inductor de entusiasmos, el de un consejero mayor de edad, siempre desde un plano marginal» ${ }^{7}$.

Guillermo de Torre echa en cara a Rafael Cansinos Assens su falta de implicación dentro del movimiento al no participar en momentos significativos de afirmación exterior como fueron las veladas de Parisiana y del Ateneo. Lo cierto es que Cansinos mantiene un alto grado de independencia dentro de lo que se pretendía convertir en una secta, y cuando lo juzga oportuno, mediados de 1921, decide abandonar el barco. En tales circunstancias le escribe a Guillermo de Torre:

Nunca, usted lo sabe, me he arrogado jefatura alguna, en el movimiento Ultra - mi actitud ha sido de un effacement, que por desgracia no ha sido estimado; pero si eso no fuera bastante, cedo desde ahora a quien lo desee toda paternidad

${ }^{5}$ VANDO-VILLAR, Isaac del. «El Divino Fracaso». Grecia, 1 de febrero de 1919, n. ${ }^{\circ}$ 8, p. 15.

${ }^{6}$ CANSINOS ASSENS, Rafael. La novela de un literato. 2, Madrid: Alianza Editorial, 2005, p. 471. El libro de bolsillo, 5082.

7 TORRE, Guillermo de. Literaturas europeas de vanguardia. Barrera lópez, José María (ed.). Sevilla: Renacimiento, 2001, p. 76. Biblioteca de rescate, 1. 
y primogenitura sobre toda bandera o lema de arte. Ya dejé de figurar entre los colaboradores de Reflector y espontáneamente me retiro de Ultra. Toda corona posible ha sido abdicada ${ }^{8}$.

Por esta misma época al ultraísmo comenzaban a abrírsele vías de agua. Una de ellas podía ser esta deserción, otra la falta de cohesión del grupo que se hizo notar de modo especial con motivo de la celebración de las dos veladas ultraístas. Guillermo de Torre sitúa la fecha de defunción del movimiento cuando la revista Vltra publica su último número, aunque marca como detonante el desastroso desarrollo de la segunda velada celebrada en el Ateneo:

El Movimiento Ultraísta, como tal, como bloque colectivo, destinado a ejercer una acción conjunta y a mantener un estado de espíritu radical y renovador, pudo en realidad considerarse como disuelto al dejar de publicarse periódicamente Vltra en la primavera de 1922, y tras el primer golpe a la solidaridad sufrida un año antes, con ocasión de la segunda velada ultraísta. Allí quedó patente la dificultad de prolongar la acción colectiva exterior, tanto por incompatibilidad de ciertos caracteres, como por la ausencia de un mínimo de disciplina necesaria ${ }^{9}$.

De Torre, buen conocedor del desarrollo de los movimientos vanguardistas europeos, nota la falta de unidad, entre otras razones por carecer de un líder neto, que aqueja al ultraísmo. Él mismo apunta, no obstante, como nota peculiar y positiva de la aventura vanguardista española el hecho de dar rienda suelta a sus participantes en su búsqueda de lo nuevo, sin tener que someterse a patrones preestablecidos o impuestos desde arriba. El ultraísmo no es una escuela, se repite insistentemente. Esta indefinición tuvo, según apunta Vicente Jarque, algún efecto benéfico:

Es cierto que la vanguardia española, salvo las grandes excepciones universalmente reconocidas, fue débil, confusa e intempestiva. Es verdad que no logró articularse en movimientos bien organizados: pero, de este modo, se libró también de las grandes dosis de sectarismo que cubrieron el continente ${ }^{10}$.

El dadaísmo, el surrealismo o el creacionismo no estuvieron exentos de fuertes polémicas provocadas en unas ocasiones por el establecimiento de la paternidad del movimiento (caso de la pugna Reverdy-Huidobro a cuenta del creacionismo) o por la expulsión de miembros poco comprometidos con las tesis marcadas por el líder correspondiente. En este sentido, el Segundo Manifiesto de André Breton es una buena muestra del espíritu bronco que a la vanguardia del primer tercio del siglo XX le fue propicio. Allí el autor de Les

${ }^{8}$ La carta de Rafael Cansinos Assens a Guillermo de Torre está fechada en Madrid el 8 de agosto de 1921. Con el n. ${ }^{\circ} 66$ se recoge en GARCÍA, Carlos. Correspondencia Rafael Cansinos Assens / Guillermo de Torre, 1916-1955. Madrid / Frankfurt am Main: Iberoamericana / Vervuert, 2004, p. 172.

9 TORRE, Guillermo de. Literaturas europeas de vanguardia, p. 108.

10 JARQUE, Vicente. «La vanguardia artística». En La vanguardia en España. Arte y Literatura. de PÉREZ BAZO, Javier (ed.). Toulouse: C.R.I.C and OPHRYS, 1998, p. 383. 
champs magnetiques se despacha a gusto con «los granujas, los impostores, los arrivistas, los falsos testigos y los delatores» ${ }^{11}$ que pululaban por las riberas del surrealismo, a los cuales se tilda de «traidores» y se procede a expulsar de inmediato. Breton, desde su posición de jefe máximo del movimiento surrealista, se convierte en una especie de Torquemada que expide certificados de aptitud a todo aquel que pretende comulgar con sus tesis. Los «doce» autores sacrificados por Breton le responden asimismo con un panfleto insidioso que maléficamente titulan «El cadáver». Si bien las aguas de la vanguardia hispana, como afirma Vicente Jarque, no estuvieron tan tintadas de sectarismo, no es menos cierto que tampoco faltaron las polémicas intensas, como puede ser el caso de la diatriba mantenida por Guillermo de Torre y Vicente Huidobro a cuenta de la originalidad y la paternidad del creacionismo, una polémica que se alarga en el tiempo hasta finales de los años 60. La falta de un jefe supremo, encargado de conceder visados de vanguardismo, como pudiera ser Breton dentro del surrealismo, no evitó que dentro del ultraísmo, amén de deserciones voluntarias, como pudiera ser la de Rafael Cansinos Assens, se produjeran también procesos inquisitoriales contra escritores vacilantes a los que se procedió a expulsar. Este es el caso de Ernesto López-Parra, el único poeta ultraísta «excomulgado» del movimiento. López-Parra provenía, como la mayor parte de sus camaradas vanguardistas, del modernismo epigonal. Junto a autores como Rafael Lasso de la Vega practicó a lo largo del período de vigencia del ultraísmo una especie de juego a dos bandas que le permitía alternar versos plenamente vanguardistas en revistas como Grecia, Gran Guignol o Vltra al lado de otros más tradicionales que enviaba a Los Lunes de El Imparcial. López-Parra tenía una visión abierta de la práctica poética, ajena a limitaciones o fronteras. Compartía con el ultraísmo su afán renovador, así como su espíritu integrador y abierto, exento de sectarismo. Este mismo espíritu es el que anidaba en otros autores coetáneos como Gerardo Diego quien también alternará versos de avanzada al lado de otros mucho más tradicionales. Por eso, antes de centrarnos en el paso accidentado de Ernesto López-Parra por el ultra y en su final expulsión, resulta pertinente echar un vistazo a la situación de Gerardo Diego dentro del ultraísmo, a su postura poco amiga de ortodoxias.

\section{Gerardo Diego, VANGUARDista HETERodoxo}

Uno de los rasgos que caracterizan a los poetas del 27, Gerardo Diego incluido, tiene que ver con su capacidad para entablar un diálogo fructífero entre la tradición y la modernidad. Ese diálogo también fue ensayado por el ultraísmo, aunque a veces no se haya reparado suficientemente en ello. Jorge

${ }^{11}$ BRETON, André. Manifiestos del surrealismo. Madrid: Visor libros, 2002, p. 120. Visor Literario, VI. 
Luis Borges, por ejemplo, enlazó el cultivo de la imagen ultraísta con la práctica de poetas barrocos como Quevedo o con las teorías estéticas que sustentaba Baltasar Gracián al proclamar que más valían quintaesencias que fárragos $^{12}$. Por su parte, Guillermo de Torre se sitúa bajo la advocación de Quevedo y de Góngora en alguno de los poemas que componen su único libro de versos: Hélices $(1923)^{13}$. El genio cordobés, tan dado al circunloquio expresivo y a atiborrar sus composiciones de neologismos es sin duda un referente ineludible a la hora de estudiar el período ultraísta del autor de Literaturas europeas de vanguardia. La prosa de ese primer momento se irá con los años simplificando, cosa que sucederá con la mayor parte de los escritores que se adhieren en su juventud al ultraísmo. El mismo Borges, que renegará con el tiempo de aquel sarpullido neobarroco, confesará en sus últimos años su predilección por una lengua mucho más natural y sencilla, despojada de cualquier voluptuosidad retórica.

Si bien en el ultraísmo, como vemos, se produce ese diálogo con la tradición que hace triunfar a los hombres del 27, el motivo de su fracaso debe buscarse en otro lugar. El ultraísmo fue capaz de enterrar un modo de hacer poesía que ya no daba para más: la modernista; también consiguió acompasar la hora literaria española con la europea; sin embargo, careció de grandes personalidades poéticas capaces de elevarse por encima del tono medio dominante y de hacerse dueños de una voz sólida que les aquilatara como creadores. Caso opuesto al de las grandes voces del 27, capaces de aclimatar aires vanguardistas como el surrealismo francés dentro de su obra, sin por ello perder un ápice de personalidad. Esa falta de voces acendradas, confiesa Cansinos Assens en el capítulo «Adiós al Ultra» de sus memorias, es lo que finalmente le convence de la inutilidad de proseguir en la lucha, después de haber sido uno de los principales valedores del ultraísmo:

${ }^{12}$ En un artículo aparecido el 23 de octubre de 1921 en El Diario Español de Buenos Aires, Borges se defiende de las acusaciones de extranjerismo que sobre el ultraísmo hacía pesar Manuel Machado en un artículo anterior («Ultraísmo y citaísmo». La Libertad. Madrid: 1 de julio de 1921). Borges enlaza el ultraísmo con el período áureo: «Éste [Manuel Machado] crimina al ultraísmo de ser una tendencia forastera e importada, sin raigambre española, y le busca una genealogía en las teorizaciones de Stephane Mallarmé. (...) la tendencia a escribir en sucesión de imágenes — tendencia que Machado apunta como la exteriorización más resaltante de la lírica ultraica - campea en nuestros clásicos, y no sólo en poetas conscientemente marginales y banderizos como don Luis de Góngora, sino en Calderón, en Baltasar Gracián, y con principalísimo relieve, en Quevedo». El artículo se reproduce en BORGES, Jorge Luis. Textos recobrados. 1919-1929, Barcelona: Emecé, 2002, p. 108.

${ }^{13}$ La sección séptima del poemario, titulada «Kaleidoscopio», está presidida por una cita de Las Soledades de Góngora. De igual modo, el primer poema de esa misma sección, «Diagrama mental», se abre con la cita de otro poeta barroco: Quevedo. TORRE, Guillermo de. Hélices. Madrid: Mundo Latino, 1923, pp. 84 y 85. 
Empiezo a pensar si Astranilla $^{14}$, el salvaje, no tendrá razón en sus crudos juicios sobre los ultraístas... Hasta ahora, no ha surgido el poeta que esperábamos. Sus producciones forman una antología de absurdos que justifican las burlas de que son objeto... y los reproches que me hacen las personas serias...: -Pero, ¿cómo da usted calor a esos cretinos? ${ }^{15}$.

Gerardo Diego es el único poeta español que tras su paso por el ultraísmo logra hacerse un nombre propio dentro de la poesía del siglo XX. Probablemente porque contempla la experiencia vanguardista con ánimo crítico, sin dejarse llevar por la fácil condena de todo lo precedente. De esa visión nada ortodoxa que del ultraísmo tenía el autor de Versos humanos puede ser buena muestra la opinión que le suscita la presentación del primer libro de León Felipe, Versos y oraciones de caminante (1920), que tiene lugar en el Ateneo de Madrid en 1919. Diego acude a aquella conferencia espoleado por sus «compañeros de Grecia», en la idea de que las palabras de León Felipe iban a causar revuelo puesto que «se iba a meter» ${ }^{16}$ con ellos. León Felipe desgrana sus principios como poeta, entre los cuales se encuentra su oposición a todo aquel creador que pretende forjar su obra al amparo de un paraguas grupal:

Con estos hombres - preceptistas o ultraístas - que se juntan en partida para ganar la belleza, no tiene nada que ver el arte. La belleza es como una mujer pudorosa. Se entrega a un hombre nada más, al hombre solitario, y nunca se presenta desnuda ante una colectividad ${ }^{17}$.

Otro motivo de crítica que según León Felipe cabe hacer a los autoproclamados «poetas nuevos», tiene que ver con su afrancesamiento, con el repudio que manifiestan hacia la rica tradición española:

Ir a buscar este valor personal, este signo específico generador de nuestro verso fuera de nosotros mismos, es una gran torpeza; e ir a buscarle fuera de nuestra tradición y de nuestro pueblo, es una gran locura. En el verso de un poeta nuevo, por mucha personalidad que tenga, ha de haber siempre ritmos de su raza, lo específico de su pueblo, que es lo genérico del poeta, y por encima de esto el signo particular de él ${ }^{18}$.

${ }^{14}$ Obviamente, Luis Astrana Marín, crítico sumarísimo de todos los movimientos de vanguardia que surgen en el primer cuarto del siglo XX. En su libro Gente, gentecilla y gentuza, lanza gruesas invectivas contra los poetas del Ultra, que no ahorran el insulto personal.

${ }_{15}$ CANSINOS ASSENS, Rafael. La novela de un literato, 2, p. 481.

${ }^{16}$ DIEGO, Gerardo. «Prólogo». En FELIPE, León. Obra poética escogida. Madrid: Espasa-Calpe, 1975 , p. 45.

${ }^{17}$ FELIPE, León. Obra poética escogida, p. 69.

${ }^{18}$ Idem, pp. 70-71. Dámaso Alonso también echará en cara al ultraísmo su olvido de la tradición española, algo que, en su opinión, le diferencia de la actitud que mantienen los hombres del 27: «(...) la generación de antes de 1936, aunque abierta a muchos influjos exteriores, está profundamente arraigada en la entraña nacional y literaria española; el complejo ultraísta se pone ropas hechas, y casi todas se han hecho fuera de casa». (ALONSO, Dámaso. Poetas españoles contemporáneos. Madrid: Gredos, 1969, p. 163. Biblioteca Románica Hispánica, Estudios y ensayos, 6). 
Estas opiniones causaron, como es lógico, estupor entre los ultraístas que rápidamente contestaron a León Felipe desde las páginas de Grecia $^{19}$. Sin embargo, a Gerardo Diego aquellas palabras le parecieron correctas y que en nada colisionaban con sus convicciones ultraístas:

El poeta habla, lee con voz triste y apacible, nada combativa, palabras muy sensatas, con las que yo, en gran parte, me siento conforme, aunque no con sus recelos y su aire de consejo. A mí, según le escucho, me parece tan bien su posición -y en seguida sus versos- como comprendo la de mis amigos ${ }^{20}$.

Gerardo Diego entabla amistad con León Felipe ese mismo día y poco después aprovechará los restos de papel de la edición de Versos y oraciones de caminante para publicar su primer poemario: Romancero de la novia. Aparece éste en 1920, en pleno fragor ultraísta, si bien se trata de una obra completamente alejada de la vanguardia. De hecho, cuando Guillermo de Torre le pide un ejemplar, Diego se protege de la segura crítica diciendo que se trata de una obra escrita para consumo interno, no venal, a distribuir entre sus amigos más allegados ${ }^{21}$. Diego era de este modo otro de los muchos poetas «ambidextros» que pululaban por el ultra, para estupor de los comisarios de la vanguardia más intransigentes. Ese espíritu dual habrá de ser rasgo distintivo del poeta santanderino a lo largo de su vida, pues compaginará una poesía de tipo tradicional junto a otra que él llama «de creación» o «absoluta», nacida de las ideas de Vicente Huidobro. Esa temprana fidelidad al poeta chileno se hace notar de inmediato, y de ello hallamos muestra en la visita que, en compañía de León Felipe, realiza en el mes de marzo de 1920 a Juan Ramón Jiménez. El autor de Diario de un poeta recién casado mantuvo una actitud un tanto ambivalente hacia el ultraísmo, pues colaboró en una de sus revistas, Reflector, señalando que en ella se encontraba «mucho mejor que entre [sus] compañeros de jeneración secos, pasados, turbios, alicaídos» ${ }^{22}$. Sin embargo, cuando, por la misma época, le visita Gerardo Diego, no parece que sintiera excesiva simpatía por los experimentos creacionistas:

19 «León Felipe, que explota sus tristezas como una prostituta sus gracias y que pasea por todos los cafés de la Puerta del Sol, se ha atrevido a juzgarnos». Citado por BARRERA LÓPEZ, José María. «Alberti en el ultraísmo». Cuadernos Hispanoamericanos, 1990, n. $^{\circ}$ 485-486, pp. 96-97.

${ }^{20}$ DIEGO, Gerardo. «Prólogo», p. 45.

${ }^{21}$ La carta, enviada por Gerardo Diego a Guillermo de Torre desde Soria el 9 de noviembre de 1920, puede leerse en NEIRA, Julio. «Fidelidad creacionista de Gerardo Diego». Ínsula, 2000, pp. 23-27, n. ${ }^{\circ} 642$.

22 Jiménez realiza esta afirmación en la carta que el 22 de noviembre de 1920 dirige a Ciria y que, en compañía de tres poesías «inéditas», se publica en el único número de $R e$ flector. Entre otros lugares, la carta ha sido reproducida en CIRIA Y ESCALANTE, José de. Obras. Díez de Revenga, Francisco Javier (ed.). Santander: Universidad de Cantabria, 2003, p. 59. Cantabria 4 estaciones, 24. 
Y allá vamos. Cuatro horas de conversación, más bien soliloquio del tan excelso como implacable poeta que intenta convencerme de lo errado de mi rumbo y de la necedad, o poco menos, de la poesía de Vicente Huidobro. Yo sostengo, como puedo, mi convicción y León Felipe apenas interviene ${ }^{23}$.

Disponemos también del testimonio de Juan Ramón acerca de aquella visita pues lo transmutó en sustancia literaria en su poema en prosa Tiempo. Justamente el paso del tiempo sumado a la inquina que hacia León Felipe demuestra tener el poeta de Moguer, hace que sus juicios no concuerden con la impresión de Gerardo Diego. Sin embargo, persiste su visión negativa del creacionismo:

Qué caso éste y qué pobre este León Felipe. Gerardo Diego me lo trajo a casa $(1917$, creo) y casi lo tenía olvidado. (...) Vicente Huidobro, con quien por cierto siempre me he portado tan mal sin que pueda esplicarme yo mismo por qué, aparte de lo literario, me había enviado aquel día su Horizon carré y L[eón] F[elipe] dijo tales modestas vaciedades contra Huidobro y sus secuaces, Gerardo Diego entonces lo era, que yo, que empecé por tomar el libro a broma, especialmente por su forma tipográfica amanerada e inútil, acabé por defenderlo, porque tenía bastante con qué defenderlo contra tal incompetencia ${ }^{24}$.

Gerardo Diego, pese a todo, hará caso omiso de toda crítica que se dirige hacia Huidobro. En sus teorías, muy próximas al cubismo pictórico, encuentra el santanderino una fértil veta de inspiración. El creacionismo convierte al poeta en un Dios, y le dota de poderes extraterrenos que le permiten «crear» nuevas realidades, ajenas a todo lo que nos rodea, y que exige de un lector especial, cómplice, capaz de sugestionarse con un lenguaje diferente. Gerardo Diego y Juan Larrea serán los discípulos españoles más fieles al maestro, si bien ambos establecerán ciertas distancias con él pues descreen de las ortodoxias. Así lo manifiesta en fecha temprana Gerardo Diego en una interesantísima carta dirigida a José Ortega y Gasset. La misiva, que va acompañada de un bosquejo de su libro ultraísta-creacionista Imagen, pone de relieve la visión abarcadora que con respecto a la historia de la poesía tiene Gerardo Diego, y que no le permite renegar de nada, ni siquiera del simbolismo, aquello que se había convertido en principal diana de sus compinches del ultra:

Creo que el creacionismo, no en el sentido ortodoxo en que lo quiere su inspirador Vicente Huidobro, sino como nuevo horizonte amplio, poético y artístico en el que quepa la mayor libertad individual, es algo tan verdaderamente puro y tan distinto de lo anterior que, por primera vez, el poeta de nuestros días deja de mirar al de la generación antecesora como el enemigo urgente e inmediato... Pues bien, yo creo que el poeta de hoy es compatible con todos y con todo. No le estorba el simbolismo ni el futurismo, ni aun el romanticismo, porque no es una consecuencia de ello (por reacción, como solía ser)... No se trata de combatir, sino de cons-

${ }^{23}$ DIEGO, Gerardo. «Prólogo», p. 47.

${ }^{24}$ JIMÉNEZ, Juan Ramón. Tiempo y espacio. Villar, Arturo del (pról. y notas). Madrid: Edaf, 1986, pp. 66-67. Biblioteca Edaf de Bolsillo, 175. 
truir. Es más, creo que el poeta creacionista puede ser a la vez romántico y simbolista... Yo al menos así lo entiendo y aun lo practico ${ }^{25}$.

Estas palabras, que en apariencia pueden entenderse como una crítica al maestro, son sin embargo desarrollo de sus ideas. Huidobro cree más en el poeta que en las escuelas, en la poesía antes que en sus vicisitudes históricas. Así lo resalta Gerardo Diego en un artículo dedicado a Vicente Huidobro y su escuela escrito años después del fallecimiento de éste:

Hablar de la poesía de Vicente y hablar del creacionismo suyo viene a ser lo mismo, pero yo he querido poner por delante y preferir «poesía» a «creacionismo». Poeta a escuela o movimiento. Sé que así soy más fiel a su escala de valores. (...) En su libro Pasando y pasando (...) decía ya a los veintiún años de edad: «Para mí no hay escuelas, sino poetas. Los grandes poetas quedan fuera de toda escuela y dentro de toda época. Las escuelas pasan y mueren. Los grandes poetas no mueren nunca» ${ }^{26}$.

Diego es poco amigo de corsés estéticos que constriñan la necesaria libertad con que el escritor debe enfrentarse a la página en blanco. Por eso, el ultraísmo, que exigía un alto grado de compromiso en sus discípulos, tarde o temprano se tenía que convertir en una frontera insoportable para quien tenía unas miras mucho más amplias. Mientras el Ultra trata cada vez más de repeler a todo aquel cultivador que manifestase la más mínima veleidad tradicionalista y de crear un grupo lo más cohesionado y unívoco posible, Diego y otros escritores tenidos por vacilantes comienzan a apartarse voluntariamente de él. También habrá algún caso, como el de Ernesto López-Parra, en el que la ruptura será traumática, pues no será él quien libremente se aleje del Ultra, sino un comité abstracto e impersonal el que decida su expulsión.

\section{CRÓNICA DE UNA EXCOMUNIÓN}

Si bien falto de cohesión y por tanto con un alto grado de permisividad creativa, al ultraísmo no le faltaron ciertas dosis de sectarismo. Teorizadores como Guillermo de Torre veían con buenos ojos que los poetas adheridos al movimiento experimentasen nuevas fórmulas, pero a la vez se manifestaban muy críticos con las concesiones que seguían haciendo al modernismo, la estética que se pretendía superar. Esas contaminaciones se daban en la mayor

${ }^{25}$ La carta, datada en junio de 1921, fue publicada por primera vez con el título de «La poética de Gerardo Diego». Suplemento «Libros». En El País, 8 de mayo de 1983, p. 6. Después se incluye en MÁRQUEZ, Margarita. «Correspondencia: Gerardo Diego-José Ortega y Gasset (1921-1932)». Revista de Occidente, marzo de 1996, n. ${ }^{\circ}$ 178, pp. 5-18.

${ }_{26}^{2}$ DIEGO, Gerardo. «Poesía y creacionismo de Vicente Huidobro». Cuadernos Hispanoamericanos, 1968, n. ${ }^{\circ}$ 222. Citamos por DIEGO, Gerardo. Obras Completas, Prosa, Tomo VIII. Prosa Literaria. En BERNAL, José Luis (ed. e intr.). Madrid: Alfaguara, 2000, vol.3, p. 194. 
parte de los ultraístas, De Torre incluido, pues todos habían aprendido a versificar bajo esa falsilla. En principio, el Ultra no fue muy estricto con ese hibridismo, y permitió que las páginas de Grecia se llenaran de poemas en los que anidaban las fragancias finiseculares al lado de los caligramas, muchas veces todo ello mezclado en un mismo poema. Sin embargo, pasado el período de formación, poco a poco se fue extendiendo un deseo de depuración, de destierro de todo lo que sonaba a viejo y caduco. Guillermo de Torre será uno de los encargados, desde las páginas de Grecia, de proceder a la tala de los árboles añosos. Para ello se servirá de un procedimiento muy práctico: emboscarse tras el anonimato para arremeter contra todo lo considerado aborrecible. En las páginas finales de Grecia se da cobijo a una sección sin firma, titulada «Panorama ultraísta», que se emplea para atar en corto a los autores próximos o para polemizar con otros, a los que Guillermo de Torre llamaba «saurios», y que venían a ser gentes como Manuel Machado, Luis Astrana Marín o el mismo León Felipe, autores renuentes a prescindir del legado de la tradición. Ese deseo de depuración se ve muy claro en la carta que a finales de 1920 dirige Guillermo de Torre a Gerardo Diego, en donde se pone de relieve que más que un deseo la purga es ya una realidad en las páginas de Grecia, de donde subraya De Torre «ya se han depurado todas las firmas equívocas ${ }^{27}$. Es difícil saber cuales habían sido las cabezas decapitadas pues a Grecia le restaban apenas un par de números más por aparecer: el último se publica en noviembre de 1920. Esa labor depuradora tuvo por fuerza que postergarse hasta hacerse efectiva en otra publicación próxima a ver la luz. En enero de 1921 sale a la calle Vltra, la revista más interesante y conformada del movimiento, entre otras razones porque es la que de modo más estricto trata de despojar de sus páginas a todos los poetas que manifiestan la menor indecisión en su militancia vanguardista. Para ello no dudó en recurrir a medidas disciplinarias extremas como la «excomunión», en aras de alcanzar una mayor uniformidad. El poeta expulsado será Ernesto López-Parra, cuyo paso por el Ultra fue casi siempre polémico, a causa de la visión abierta que con respecto a la práctica poética sustentaba, y que con el tiempo le llevará a convertirse en la cabeza de turco con la que el movimiento ultraísta tratará de conjurar sus fantasmas.

Ernesto López-Parra ${ }^{28}$, nacido en Talavera de la Reina (Toledo) en 1895, publicó sus primeros versos en las revistas madrileñas Cervantes y Los Quijotes, las mismas en donde se curten los poetas próximos a Cansinos que pronto se van a pasar con armas y bagajes al ultraísmo. Su primer poema dentro de esta orientación aparece en la revista Cervantes en junio de 1919, dentro

${ }^{27}$ La carta, fechada el 27 de octubre de 1920, puede consultarse en NEIRA, Julio, art. cit., p. 25.

28 Sobre este autor véase ROJAS, Pablo. Ernesto López-Parra, el ultraísta remolón. Talavera de la Reina: Ayuntamiento, 2006. Col. Padre Juan de Mariana, 27. 
de una antología de poetas ultraístas realizada justamente por Rafael Cansinos Assens. El poema lleva por título «Los nuevos aeroplanos» y es ya signo distintivo de la heterodoxia con que López-Parra se enfrenta a la tarea de escribir poesía, pues enlaza la admiración hacia los avances de la modernidad de estirpe futurista con cierto tono reivindicativo, de ascendente políticosocial. Tras este bautismo vanguardista se sucederán las colaboraciones en Grecia, Gran Guignol, Vltra (Oviedo), Vltra (Madrid) o Cosmópolis, es decir, en las principales «bocinas» del ultraísmo. Los poemas que publica allí, aun con ciertas concesiones al modernismo, están muy influidos por el futurismo y el creacionismo, y tienen como principal argumento el cultivo de imágenes, lo que habrá de constituirse en el legado más estimable del ultraísmo. Mientras colabora en Grecia, se produce la aparición de su primer libro de versos: Poemas del Bien y del Mal (Madrid, Artes Gráficas, 1920). El libro nace a destiempo pues viene a recoger su poesía anterior, de fondo y forma modernistas. Este hecho le ocasiona las primeras fricciones con sus compañeros ultraístas, que amparados en el anonimato no tardan en reprenderle desde las páginas de Grecia. No obstante, le dan un voto de confianza por tratarse de una publicación extemporánea, nacida de modo inoportuno. Dentro de la polémica sección «Panorama ultraísta» se leen así las siguientes observaciones:

\begin{abstract}
Hemos leído el libro de Ernesto López-Parra, titulado Poemas del Bien y del Mal. Si no conociéramos toda la labor de este poeta y no hubiéramos asistido de cerca a su evolución, reprocharíamos a López-Parra la publicación de este último libro y le señalaríamos con el dedo rojo las influencias que le desfiguran y amenguan. Considerando el libro, sin embargo, como una inevitable reminiscencia, nos limitamos sólo a desear vivamente la publicación de Las Fuentes del Silencio, donde seguramente vibrará todo el temperamento del poeta ${ }^{29}$.
\end{abstract}

Se trata por tanto de un primer aviso. Por otra parte, ese anunciado segundo libro, Las Fuentes del Silencio, que habría de estar más apegado a la vanguardia, no llegó a aparecer. Fue uno más de los muchos libros ultraístas prometidos que no tuvieron la fortuna de hallar editor. Pese a todo, podemos hacernos una idea bastante cabal de su espíritu porque López-Parra desperdigó por varias revistas ${ }^{30}$ algunas de las composiciones que lo habrían de conformar. Esos poemas ponen de manifiesto que el autor talaverano no se había despojado del todo de sus viejas querencias rubendarianas. Esa vacilación es probable que le costara la exclusión de Grecia en los dos números siguientes, los últimos que se publican. Ya hemos visto más arriba, que justamente en este momento, septiembre de 1920, Guillermo de Torre manifiesta a Ge-

${ }^{29}$ Grecia, 1 de septiembre de 1920, XLVIII, p. 16.

30 «Jardines evocativos: La romanza. La evocación. Surtidor». Ultra (Oviedo), 1 de enero de 1920, pp. 34-35; «Las fuentes del silencio: Evocación. Mariposa». Grecia, 31 de enero de 1920, n. ${ }^{\circ} 39$, p. 7 ; «Fuentes del silencio: Horas. Bálsamos. Nocturno». Cervantes, octubre de 1920, pp. 31-32. 
rardo Diego la necesidad de purgar la revista de elementos vacilantes. En los números XLIX y L de Grecia, aparecidos el 15 de septiembre y el 1 de noviembre de 1920 respectivamente, no aparece la firma de López-Parra. Es difícil saber si ello es debido a la falta de colaboraciones o a hallarse inserto dentro de ese grupo de autores poco comprometidos de los que, al menos en la mente de Guillermo de Torre, había que desprenderse. Esta última hipótesis no parece descabellada, si bien es cierto que, al menos inicialmente, López-Parra no va a tener problemas para publicar en la exigente Vltra.

A Grecia le habrán de suceder dos nuevas revistas de similar militancia vanguardista: Vltra y Reflector. Antes de detenernos en la primera de ellas, conviene echar un vistazo a la segunda, la revista fundada por el malogrado poeta cántabro José de Ciria y Escalante, buen amigo de Gerardo Diego, y cuya génesis pone de manifiesto ciertas tensiones dentro de las filas ultraístas, debidas, entre otras razones, a las polémicas que la anónima sección «Panorama ultraísta» suscitaba. Gracias a una carta que Ciria dirige a Gerardo Diego y que ha sido exhumada por el profesor Julio Neira, sabemos que hubo un intento de reflotar Grecia, y que a esa nueva etapa se le pretendía dar un aire más plural, menos uniforme, del que se erradicara toda crítica extemporánea escrita bajo la impunidad que da el anonimato: «he suprimido el panorama y esa página que se perdía molestando a la gente se aprovechará en algo interesante» ${ }^{31}$, resalta Ciria. El único número que se llega a publicar de esta revista aparece en diciembre de 1920. En él no hay ninguna colaboración de Ernesto López-Parra, si bien su firma se incluye dentro de la larga lista de colaboradores futuros con que dice contar el editor.

Apenas unos días después de desaparecer Reflector, surgirá Vltra, cuyo impactante primer número llega a los quioscos en enero de 1921. Su disposición en forma de tríptico y sus llamativas portadas con xilografías de Barradas o de Norah Borges no dejan indiferente a nadie: Eugenio D'Ors le dedica por entonces una glosa en la que destaca la potencia visual de su formato, y también Rafael Alberti deja constancia en sus memorias, La arboleda perdida, del soplo renovador que la revista venía a representar. La edición de Vltra daba cumplimiento a uno de los presupuestos con que el movimiento ultraísta se había presentado en sociedad. En su manifiesto fundacional se prometía la publicación de una revista encargada de ser el estandarte de la nueva poesía: «Por el momento, creemos suficiente lanzar este grito de renovación y anunciar la publicación de una Revista, que llevará este título de Ultra, y en la que sólo lo nuevo hallará acogida ${ }^{32}$. Dos años más tarde el deseo se hace realidad, si bien en el ínterin ya ha nacido otra revista bajo la cabecera de Vltra en Oviedo. Es importante resaltar esa coletilla de que sólo

${ }^{31}$ La carta, fechada el 13 de noviembre de 1920, queda recogida en NEIRA, Julio, art. cit., p. 26.

${ }^{32}$ BRIHUEGA, Jaime, op. cit., p. 102. 
lo nuevo encontrará cobijo dentro de la anunciada revista, porque, efectivamente, tras la sucesión de publicaciones de corte vanguardista con ánimo abarcador la madrileña Vltra estará animada por un espíritu mucho más selectivo y exigente.

Son variados los testimonios de los participantes en el ultraísmo que hablan de la heterogeneidad de sus oficiantes. Una heterogeneidad debida, entre otras razones, al carácter híbrido de sus fundamentos. También a la libertad que daba a sus creadores el hecho de presentarse como movimiento o tendencia, nunca como escuela. Sin embargo, tal laxitud era vista con malos ojos por quienes pretendían conseguir un cierto grado de uniformidad dentro del grupo. Guillermo de Torre era uno de ellos. Otro lo será Humberto Rivas, neoconverso al ultraísmo, que se va a erigir en uno de los más celosos guardianes de la ortodoxia vanguardista. De hecho, como señala Guillermo de Torre $^{33}$, será el auténtico director de Vltra, por más que ésta pregonara que en su cúspide habitaba la nada. Existen pruebas suficientes del deseo de orillar del ultraísmo a los poetas poco comprometidos y en los que se daba cierto diletantismo. Así lo prueba una carta que envía Joaquín de la Escosura, director de la Vltra ovetense, a Vicente Huidobro en febrero de 1920: «no hay más ultraístas sinceros en España que once. Los demás ni sienten el ultra ni saben lo que es» ${ }^{34}$. De la Escosura escribe estos juicios una vez ha llegado a su término la edición de la revista que dirige, la cual sólo alcanza a publicar cinco números entre noviembre de 1919 y enero de 1920. De nuevo, se posterga la cura de un mal endémico que se le prescribe al ultraísmo: su falta de unicidad, la dispersión de sus miembros en un haz de direcciones a veces enfrentadas. Tal objetivo lo va a asumir con inusitado rigor el núcleo directivo de la nueva Vltra. En una carta que envían Humberto Rivas, su hermano José Rivas Panedas y Tomas Luque de nuevo a Vicente Huidobro en diciembre de 1920, poco antes por tanto de su nacimiento, se apunta claramente el ánimo purificador con que nace la nueva revista: «creemos llegada la hora de realizar una profunda selección entre los valores que iniciaron el movimiento ultraísta en España y estamos a punto de lanzar una nueva publicación encauzada en este sentido» ${ }^{35}$.

En el primer número ya se hace constar que la revista viene a cumplir un compromiso adquirido tiempo atrás: «Hoy con la publicación de ULTRA se cumple el último compromiso asumido por los firmantes del manifiesto que bajo este título apareció en todos los diarios madrileños en el otoño de 1918. Todo lo que en él nos proponíamos se halla realizado plenamente» ${ }^{36}$. También

${ }^{33}$ TORRE, Guillermo de. Literaturas europeas de vanguardia, p. 80.

${ }^{34}$ La carta se recoge en el número monográfico dedicado por la revista Poesía a Vicente Huidobro, invierno de $1988-1989$, n. $^{\text {o } 30-32, ~ p p . ~ 142-143 . ~}$

35 Idem, p. 143.

36 Vltra, 27 de enero de 1921, n. ${ }^{\text {o } 1 .}$ 
se destaca el hecho de que la publicación careciera de director al estar en manos de un «comité directivo anónimo», o que se sustentaba bajo un firme propósito de «selección», puesto que «venía a recoger lo que hay de valioso y maduro en el espíritu que ha alentado en las revistas Grecia, Cervantes, etc, etc, las cuales deberán considerarse como precursoras» ${ }^{37}$. Es obvio que entre las intenciones de Vltra estaba el propósito de tamizar un movimiento excesivamente permisivo en la fijación de sus fronteras. A pesar de los avisos previos, esto no impide que López-Parra publique en el primer número un poema titulado «Crepúsculo», consistente en una larga sucesión de imágenes, o que se anuncie su participación en la primera velada ultraísta, que iba a tener lugar el día 28 de enero de 1921 en los salones Parisiana de Madrid. Entre otros, acompañan a López-Parra César A. Comet, Tomás Luque, Humberto Rivas, Rafael Lasso de la Vega o Guillermo de Torre. La velada pondrá de manifiesto la enorme dispersión del movimiento ultraísta, debido entre otras razones a su parco andamiaje teórico. Ernesto López-Parra será quien levante las iras del grupo, al despacharse con una intervención escasamente vanguardista. Rafael Cansinos Assens refiere en sus memorias el accidentado desarrollo de aquella velada, y la polémica suscitada a raíz de la lectura de versos que realiza el poeta talaverano:

Eliodoro y el grave Comet $^{38}$ están justamente indignados con su joven colega Ernesto López Parra, el cual los traicionó a todos, descolgándose con unos versos de corte rubeniano que gustaron al público y provocaron ovaciones y gritos de «iEsto es otra cosa..., ésos son versos..., fuera los ultraístas!»

— ¡Has sido un traidor! —le increpa Heliodoro, amagándole con el índice—. Debes morirte.

López Parra, un jovencito pequeño, moreno, con unos ojillos negros, penetrantes y un modo de hablar recalcado y preciso, se justifica tomando a risa las inculpaciones de los otros:

- ¿Qué culpa tengo yo de que el público os abuchease a vosotros y a mí me aplaudiese?... Yo fui al festival de buena fe...

-Sí; pero llevaste unos versos modernistas..., y eso no está bien...

- Mis versos son tan ultraístas como los tuyos... En el Ultra cabe todo $(\ldots)^{39}$.

Eliodoro Puche va un paso más allá y propone la eliminación de esos «traidores», entre los cuales López-Parra ocuparía un lugar preeminente. Cansinos resalta las dificultades que la mayor parte de los poetas ultraístas tenían para desembarazarse de las pegajosas adherencias modernistas, y que unos y otros se dedicaban a resaltar en sus poemas de avanzada la aparición de contaminaciones «pasatistas». López-Parra no era, ni mucho menos, el único cuyo pedigrí vanguardista estaba en entredicho, pero será el encargado de pagar los platos rotos.

\footnotetext{
${ }^{37}$ Idem.

${ }^{38}$ Se trata de los poetas vinculados al ultra Eliodoro Puche y César A. Comet.

${ }^{39}$ CANSINOS ASSENS, Rafael, op. cit., p. 338.
} 
Curiosamente, en el número dos de Vltra nada se apunta de esta polémica, al contrario, «el comité directivo anónimo» considera la velada un éxito. López-Parra publica un nuevo poema: «Marchitario». Sin embargo, sí que se observan movimientos tendentes a vaciar la revista de diletantes. En uno de los típicos sueltos con que se adornan las páginas de Vltra, se lee lo siguiente: «No respondemos de los poetas que poseyendo la habilidad de laborar en dos sentidos, acuden a nuestras páginas atraídos por el éxito del ultraísmo y su fuerza subyugadora. En nuestro anhelo de amplitud acogemos todo lo que, siendo nuevo, está bien. Si después desertan, peor para ellos ${ }^{40}$. En la página siguiente, se apunta con mayor precisión: «Los poetas Lasso de la Vega y López-Parra, nuestros queridos compañeros, tienen algunas composiciones comprometidas en diversas Revistas españolas, anteriores a este movimiento. Pero de aquí en adelante todas las poesías que publiquen estarán inspiradas en esta tendencia renovadora» ${ }^{41}$. De nuevo, se le da a López-Parra otro aviso. Y lo cierto es que por entonces proseguía publicando poemas de hechura modernista en las páginas de Los Lunes de El Imparcial ${ }^{42}$. Es verdad que no era el único, pues el exigente Eliodoro Puche o Rafael Lasso de la Vega, al que también se le da un tirón de orejas, actuaban de modo similar. La situación provocó cierta incomodidad en López-Parra, de modo especial tras su actuación en la velada de Parisiana, y para tratar de disipar las dudas acerca de su militancia ultraísta envió al diario La Libertad un artículo en el que intentaba aclarar sus posiciones. Lo primero que hace constar es su oposición a todo movimiento que intente coartar la necesaria libertad del creador, en aras de obtener la mayor uniformidad posible. El ultraísmo, entendía López-Parra, había nacido como tendencia, no como escuela, sin guías ni mentores definidos, con el objeto de abrir nuevos y necesarios caminos:

El fracaso de todas las escuelas y de todos sus fundadores ha originado precisamente este movimiento, que no es, como algunos se empeñan en sostener, un movimiento de agrupación, sino, por el contrario, de dispersión, de disgregación de moléculas líricas de libertad ${ }^{43}$.

A López-Parra, como veíamos que le ocurría a Gerardo Diego, no le gustan, en poesía, las ataduras. Tampoco tener que renunciar al cultivo de la «Belleza» ni al magisterio de la tradición:

Se ha entendido mal, tal vez porque se ha explicado de un modo difuso, la aspiración del ultraísmo. Quiere presentarse a esta tendencia — tendencia nada más,

${ }^{40}$ Vltra, n. ${ }^{\circ}$ 2, Madrid, 10 de febrero de 1921.

41 Idem.

${ }^{42}$ Un listado completo de sus colaboraciones en este suplemento puede obtenerse en ALONSO, Cecilio. Índices de Los Lunes de El Imparcial (1874-1933. Madrid: Biblioteca Nacional, 2006, tomo II, pp. 1305-1306.

${ }^{43}$ LÓPEZ-PARRA, Ernesto. «Las nuevas tendencias líricas. El ultraísmo». La Libertad, 5 de febrero de 1921. 


\begin{abstract}
nunca escuela-, rompiendo no solamente con la rima y con el ritmo preceptuado, sino también con la emoción estética, con el buen gusto y la belleza.

Lo que queremos es depurar las imágenes ya creadas, no porque nos parezcan malas, sino porque nos parecen viejas. Las cosas son siempre las mismas, pero cada época las ve con ojos distintos, y la emoción que de ellas se desprende la recogemos de bien diferente manera. Fundamos nuestro anhelo depurativo en una realidad. Dentro de una misma generación existen temperamentos dispares, y cada poeta debe expresarse de un modo peculiar y personalísimo ${ }^{44}$.
\end{abstract}

Ernesto López-Parra se opone de este modo al espíritu gregario que algunos pretendían alentar dentro del ultraísmo. El elemento que a López-Parra le parece más destacable del conglomerado ultraico es su apuesta por la imagen: "iImágenes creadas, vivas, chorreantes de actualidad y siempre adornadas con la gracia de la belleza! Esa es la aspiración que sustentamos» ${ }^{45}$. Entre sus magnos cultivadores descuellan Vicente Huidobro, Philippe Soupault o Stephane Mallarmé. Esta tríada vendría a ser una especie de apostolado ultraico en el que López-Parra se inspira. De hecho, muchas de las ideas que emplea son muy similares, si no exactamente iguales, a las sostenidas por Huidobro: su concepción del poeta como ser único, ajeno a taxonomías grupales, la entronización de la imagen como principal elemento constitutivo del poema, el desprecio de la rima en beneficio de la musicalidad de la frase, etc. El creacionismo está muy presente en la teoría y en la práctica poética de Ernesto López-Parra, lo cual se aprecia en alguno de sus poemas más inspirados como es el caso de «Casa vacía», que aparecerá sin problemas en el número 8 de Vltra (20 de abril de 1921).

Pese a la polémica, López-Parra prosigue con su colaboración en Vltra en los números siguientes (hasta el 11), y participa en la segunda velada ultraísta que se celebra en el Ateneo de Madrid en la noche del 30 de abril de 1921. Según se reseña en las crónicas de la época la participación de López-Parra volvió a ser un tanto vacilante, pues junto a un poema de inequívoco sabor ultraísta — «Exaltación de la rana ultraica»— leyó otros menos militantes: «el Sr. López Parra, [participó] con un humorístico artículo y unos versos del lirismo de la vieja escuela», se apunta en el diario $L a V z^{46}$. La velada fue de nuevo bastante polémica pues no faltaron en su desarrollo las increpaciones ni los insultos, aunque una vez más al comité directivo de Vltra le pareció «un éxito clamoroso» ${ }^{4}$. La prensa acogió favorablemente la intervención de Ernesto López-Parra, al que se tenía por uno de los poetas de futuro más halagüeño dentro de los que participaban en el ultraísmo. Pocos días más tarde las cosas se precipitan de tal modo que el autor talaverano será, en palabras

\footnotetext{
${ }^{44}$ Idem.

${ }^{45}$ Idem.

${ }^{46}$ MAYRAL, José L. «Un regocijante espectáculo en el Ateneo». La Voz , 2 de mayo de 1921

${ }^{47}$ Vltra, 10 de mayo de 1921, n. ${ }^{\circ} 10$.
} 
de Rafael Osuna, «accusatus, judicatus, condemnatus» ${ }^{48}$, y definitivamente expulsado del ultraísmo. ¿Por qué? Porque días antes había cometido el sacrilegio de estrenar una obra de teatro, Paisaje de abanico, poco o nada vanguardista. Esto le pareció intolerable al núcleo dirigente de Vltra que cansado de los desplantes de López-Parra, y para que sirviera de aviso a especímenes similares, decidió tomar una solución drástica: la excomunión.

Vayamos a los hechos. El sábado 4 de junio de 1921 se estrena en el Teatro Español de Madrid la obra Paisaje de abanico, de la que es autor Ernesto López-Parra. Se trata de una pieza breve, un «poema escénico» en palabras del autor, que debía complementar a otra obra de mayor amplitud titulada Sor Teresa de Jesús. Apenas unos días después del estreno, la pieza se trasplanta a papel, dentro de la colección de obras breves que publicaba la editorial Esquemas, a cuyo frente estaba el poeta gallego Xavier Bóveda, uno de los firmantes del manifiesto ultraísta, si bien ya rondaba por otros lares. El día antes del estreno, López-Parra destaca los modestos propósitos con que nace su pieza dramática: «Paisaje de abanico (...) es sencillamente un poema sin tiempo ni lugar, acaso demasiado femenino, cuyas figuras, un poco desvaídas, evocan las de esos muñecos que aparecen en las vitelas de los viejos atavíos bordados» ${ }^{49}$. López-Parra señala que se trata de una pieza revestida de «ingenuidad», que se asienta sobre una trama de gran «sencillez». Una obra, en suma, humilde, sin pretensiones de revolucionar la escena dramática de su tiempo, que se asienta sobre una tradición inveterada en la idea de hacer pasar un rato agradable al público asistente. Esa tradición es la tradición modernista, justamente aquello que a sus compañeros del Ultra les parecía más abominable. La paciencia de los sumos sacerdotes ultraístas se vio así colmada y se procedió a expulsar definitivamente al traidor.

En el número 13 de Vltra, que aparece seis días después del estreno de Paisaje de abanico, dentro de la sección «Kaleidoscopio», se publica un artículo titulado «Un estreno», en el que se responde al reto de López-Parra: «Con pena, con hondísima y verdadera pena, asistimos a la representación de Poema de abanico $^{50}$, la obra de Ernesto López-Parra, estrenada recientemente en el Teatro Español. Con verdadera pena también escribimos estas líneas, que trazan una línea divisoria entre nosotros y un querido amigo nuestro». La obra, se argumenta, es una «caída lamentable» puesto que «no ha sido ocasionada por un noble y generoso intento de renovación». López-Parra no ha intentado epatar al público con una obra de ruptura que zarandease la modorra reinante, en cuyo caso, de haber fracasado, sus hermanos ultraístas se habrían sentido

${ }^{48}$ OSUNA, Rafael. Revistas de la Vanguardia Española. Sevilla: Renacimiento, 2005, p. 191. Iluminaciones, 18.

49 LÓPEZ-PARRA, Ernesto. «Paisaje de abanico. Autocrítica». La Tribuna, 3 de junio de 1921, p. 4. El artículo se reproduce íntegro en ROJAS, Pablo, op. cit., p. 177.

${ }^{50}$ Repárese en el error del título que ha inducido a confusión a varios cronistas de la vanguardia. 
«orgullosos de su fracaso», sino que había puesto su pluma «al servicio de los recursos más viejos y manidos», lo cual resultaba sencillamente imperdonable: «A nuestro lado», se le recrimina, «se puede incurrir en el error, jamás en la apostasía». La voz anónima del artículo destaca que López-Parra no había sido un ultraísta excesivamente comprometido con la causa, y que sus indecisiones le habían sido perdonadas por su juventud y la prueba de talento que revelaba tener, en espera de una «evolución progresiva y salvadora». Sin embargo, la contumacia del poeta en volver la vista atrás debía resolverse de una vez. Procedía por tanto, aunque con pena, su expulsión. Dicho y hecho, ya no aparecerán nuevas colaboraciones de López-Parra en Vltra.

La sección «Kaleidoscopio» que venía a ser dentro de Vltra una especie de reedición del «Panorama ultraísta» de Grecia, que tantas polémicas suscitó, estaba firmada en muchas ocasiones por Guillermo de Torre. Sin embargo, su prosa suntuosa y gongorista no casa con la que aquí encontramos, por lo que resulta más razonable pensar que el encargado de tomar la decisión drástica de prescindir de López-Parra fue Humberto Rivas, a la sazón el director de la revista. El caso es que la medida disciplinaria causó cierto revuelo en la prensa de la época. En primer lugar, porque el mismo López-Parra contestó la decisión con un artículo publicado en el diario madrileño La Tribuna. El talaverano le pone por subtítulo «Habla un ultraísta "excomulgado"»y es bien sintomático del proceso de ineludible decadencia en el que ha entrado el movimiento vanguardista español. El propio Guillermo de Torre, a toro pasado, y aunque evita pronunciarse sobre esta polémica, ya establecía que la segunda velada ultraísta celebrada en el Ateneo fue el principio del fin del Ultra en España. López-Parra titula su artículo «Poetas viejos y poetas nuevos» y comienza por dar noticia de la decisión que con respecto a su persona habían tomado sus ex compañeros:

\begin{abstract}
Mis queridos ex camaradas se reunieron en Consejo Supremo a raíz de estrenarse en el teatro Español mi fábula escénica «Paisaje de abanico» y decidieron excluirme del movimiento declarándome poeta viejo y trasnochado.

Yo acato la decisión terminante del Papa anónimo del ultraísmo, me doy por excomulgado y hasta me dispongo a entrar corrido de vergüenza en la venerable cohorte donde los ultraístas tienen ya señalado mi puesto bajo el nicho de Grilo o junto al panteón donde yacen las rimas de don Juan Antonio, el académico poeta de nuestros días ${ }^{51}$.
\end{abstract}

No está falto López-Parra de ironía ni de retranca en sus contestaciones, pues lejos de tomarse la decisión como una afrenta lo hace con humor y cierta

${ }^{51}$ LÓPEZ-PARRA, Ernesto. «Poetas viejos y poetas nuevos». La Tribuna, 17 de junio de 1921, p. 9. Gloria Videla hace referencia a este artículo (El ultraísmo. Madrid: Gredos, 1971, p. 231. [Biblioteca Románica Hispánica, col. Estudios y ensayos, 69]), aunque yerra en la fecha de publicación (ella lo sitúa en La Tribuna el 20 de junio de 1921). También nosotros, siguiendo a Videla, y tras varias búsquedas infructuosas, dejamos entre interrogantes su existencia (ROJAS, P., op. cit., p. 283). 
deportividad: «Es preciso que los hechos se aclaren, aunque esto de la claridad parezca una broma tratándose de cosas ultraístas».

López-Parra se defiende de quienes le acusan de «pasatismo» diciendo que su obra no pretendía ser renovadora, entre otras razones porque el público de teatro no era un público «seleccionado», como lo pudiera ser el que compra libros de poesía. Para éstos es para quienes, en su opinión, debía escribirse poesía de la nueva escuela. Por contra a él se le pedía algo excesivo: «Sería ingenuo y eminentemente cómico iniciar un teatro poético ultraísta, cuando aún no se ha publicado un solo libro de versos ultraístas, y ¿por qué no decirlo?, cuando ningún poeta de los que defienden la moderna tendencia podría decirnos qué es ultraísmo siquiera». En su debut teatral, si bien dentro de unos patrones clásicos, López-Parra no había evitado incluir algunos destellos vanguardistas, como pudiera ser el cultivo de imágenes, las cuales, resalta el poeta, aparecerían en gran número en la «Elegía de los jardines». López-Parra lista algunos ejemplos al respecto y concluye: «Así, pues, a mi juicio, no implica un retroceso «formal» en mi modesta labor lírica».

Tras defenderse de las acusaciones, López-Parra pasa a arremeter contra el Tribunal que se había erigido en guardián supremo de la ortodoxia ultraísta y que había tomado la resolución de expulsarle. En primer lugar, para refutar su competencia en el caso pues se pregunta: «¿quieren decirme mis queridos amigos y ex compañeros quién de ellos puede erigirse en sumo Pontífice del rito; quién puede ser definidor de una tendencia -ellos mismos declararon que el ultraísmo no es una escuela sino un movimiento, un máximo anhelo de superación-, y quién en fin, está capacitado para «arrojar la primera piedra»?». Todos los poetas que se habían sumado al Ultra eran dueños de un pasado modernista que ahora se veían en la obligación de esconder, tal y como irónicamente les presenta Rafael Cansinos Assens en sus memorias, y todavía de forma más cómica en su novela en clave El Movimiento V.P. Nadie, como les espeta López-Parra, estaba libre de pecado, y menos aún los más veteranos, aquellos en los que se agolpaba un «mayor lastre de años y de labor poética». López-Parra hace relación de los escritores que supuestamente habrían tomado la decisión de expulsarle, para demostrarles que no eran ellos los más indicados para hablar. Aunque la cita puede resultar algo larga, merece la pena recordar el retrato que de ellos se hace porque en algunos casos —Guillermo de Torre, por ejemplo— su juicio resulta profético:

No será ese Pontífice de lo nuevo Humberto Rivas, el benjamín del ultraísmo que ingresó en nuestro movimiento hace unos meses después de burlarse donosamente de la nueva tendencia y de dirigir agrias censuras a los poetas que seguíamos esta orientación. No lo será tampoco mi amigo Lasso de la Vega, con su doble personalidad clásica y «dadaísta» que le permite publicar bellísimos versos de la vieja escuela en todas las revistas de Madrid, y luego hacer en «Ultra» esas primorosas autoversiones del francés, de sus poemas, llenos de un encantador ritmo interior, y de un maravilloso exotismo. No lo será tampoco Gerardo Diego, ausente 
de Madrid y ajeno a estas cosas, y cuyos versos «creacionistas» nada tienen que ver con lo que se quiere llamar ultraísmo. Ni menos que ninguno el crítico de «Ultra» Guillermo de Torre cuya prosa cada vez más diáfana acabará siendo deliciosamente académica ${ }^{52}$.

López-Parra aprovecha la ocasión para hacer balance del ultraísmo, un movimiento al que augura un final próximo por no haber sido capaz de concretar de modo práctico sus propuestas. Al autor de La Imagen Iluminada el ultraísmo le parece una mera suma de creacionismo y de «mal dadaísmo», y le achaca su incapacidad para forjar «ideas nuevas», además de haberse disuelto en un noble pero insuficiente «anhelo de renovación». El ultraísmo, resuelve López-Parra, debía haberse ocupado menos de la imagen y más del alma del verso, de crear ideas antes que meras ristras de metáforas. Todas estas deficiencias son justamente las que años después han solido achacar al ultraísmo quienes se han acercado a él con cierto rigor. López-Parra concluye su artículo diciendo que, ahora, independizado de la «secta» en que el ultraísmo se había transformado es cuando «más libre y más joven» se sentía.

La polémica, con todo, no acaba aquí. Debemos hacer mención de otros asuntos colaterales que el estreno de Paisaje de abanico llevó adosados. En el mismo número de Vltra y en la misma sección donde se prescinde de la colaboración de López-Parra, se contestan también algunas opiniones que con motivo del estreno de la pieza se vertieron a favor del escritor y en contra del ultraísmo. En concreto, en el diario La Tribuna había aparecido una crítica sin firma en la que se animaba a López-Parra a abandonar una tendencia de la que parecía burlarse:

Ernesto López-Parra es uno de los más exquisitos poetas jóvenes, y tiene un excelente porvenir si se decide a dejar el ultraísmo. A juzgar por Paisaje de abanico, López-Parra es uno de los muchos poetas que, aun escribiendo en Ultra, son los primeros en reírse de tan funesto y descabellado sarampión. López-Parra es un poeta que sabe hacer versos difíciles, es decir, versos que no son ultraístas ${ }^{53}$.

Estos comentarios encresparon lógicamente los ánimos de la dirección de Vltra que los vino a sumar al largo rosario de improperios del que su corriente se había hecho acreedora. Ese extenso bagaje crítico era uno de sus principales nutrientes pues la polémica, como le sucedía al hermano movimiento dadaísta, constituía una de sus primerísimas razones para existir. En Vltra no pierden la ocasión de contestar tales insinuaciones:

Un periodista (...) dice que este amigo nuestro se ha estado riendo de nosotros y que podría ser uno de los poetas jóvenes de más porvenir si se decidiera a abandonar resueltamente el ultraísmo. Esta tontería sólo se le podía haber ocurrido a un periodista. En primer lugar, si López-Parra ha intentado reírse de lo único positivo y serio que existe dentro de la poesía contemporánea, peor para él. Ya ve todo lo que puede conseguir fuera del ultraísmo: que lo pongan entre la turba

\footnotetext{
52 Idem.
}

53 S.f. «La escena. Paisaje de abanico». La Tribuna. Madrid: 6-VI-1921, p. 8. 
anónima de los Castellotes y de los Merinos. A este paso, nuestro querido amigo irá derecho a la inmortalidad...

$\mathrm{Y}$ en segundo término, ¿quién le ha dicho a ese pobre gacetillero que en ULTRA hay poetas que se ríen de nuestro movimiento, del único movimiento español que ha traspasado las fronteras? Aquí únicamente nos reímos de los periodistas y de los necios ${ }^{54}$.

El resultado práctico de todo este embrollo es que López-Parra deja de publicar en Vltra y se ve impelido a abandonar un movimiento en el que ha colaborado de modo franco, por más que se le vitupere de modernista redomado e irredento. Dentro de la historia del ultraísmo, que en gran medida será escrita y orientada por Guillermo de Torre, López-Parra ocupará un lugar casi marginal. En la catalogación de los poetas ultraístas que realiza en su libro Literaturas europeas de vanguardia, en donde quedan subdivididos en influyentes, influidos, de indecisa personalidad y fluctuantes, López-Parra aparece incluido dentro del último grupo, en compañía de Rogelio Buendía, Luis Mosquera, Heliodoro Puche, Ramón Prieto y Romero, Ángel Dotor y Francisco Vighi $^{55}$. De nada sirve que unos años atrás el mismo De Torre tuviera a López-Parra por uno de los ultraístas más sinceros, o empleando su terminología, fuera un «ultraísta per nativitatem» ${ }^{56}$. El movimiento conoce en estos momentos graves tensiones que lo conducen hacia su final. Final que vendrá marcado por el cierre de Vltra, cuyo último número aparecerá el 15 de marzo de 1922. Todavía nacerán otras publicaciones de corte ultraísta (Tableros, Plural, Horizonte) que en general tendrán un ánimo más abarcador y menos inquisitivo. Por su parte, López-Parra buscará acomodo en revistas más abiertas como La Pluma o Alfar, además de seguir componiendo poemas de corte rubendariano para Los Lunes de El Imparcial. Los que publica en La Pluma y en Alfar siguen sin embargo la estela del ultraísmo, de modo especial en su gusto por el cultivo de imágenes. Además, pese a su salida poco airosa, López-Parra no renegará de su pasado ultraísta pues en su libro de 1929 La Imagen Iluminada incluirá una sección titulada «Motivos Nuevos» en donde ofrece una amplia y remozada muestra de su arte de vanguardia.

Junto a la respuesta de López-Parra, en la prensa de la época hubo alguna reacción más. En su sección humorística de $L a$ Voz, «La cena de las burlas», Enrique Díez-Canedo se hace eco de la refriega, y lo hace con ironía pues es otro de los críticos que no tenía en gran estima al ultraísmo:

Verdaderamente, el delito en sí es grave. En Paisaje de abanico, el Sr. López Parra intentó (suponemos que lo intentaría, porque eso dice que es lo que se ha de hacer), intentó superar a la Naturaleza y a la Vida. Por desgracia, según nuestros informes, no pudo superar algo que inmediatamente le importaría haber superado: no pudo superar las deficiencias de la interpretación ni el aburrimiento del

\footnotetext{
${ }^{54}$ S.f. «Kaleidoskopio. Una alusión». Vltra, 10 de junio de 1921, n. ${ }^{\circ} 13$.

55 TORRE, Guillermo de. Literaturas europeas de vanguardia, p. 106.

56 TORRE, Guillermo de. «El movimiento ultraísta español». Cosmópolis,. noviembre de 1920, n. ${ }^{\circ} 23$, pp. 473-495.
} 
público. El público, por una vez, fue más allá de lo que esperaba el poeta: es decir, se declaró más ultraísta que el Papa.

De modo que para el señor López Parra la jugada no pudo ser más desastrosa: por una parte, ningún éxito; por otra, una excomunión.

Ahora que el señor López Parra, hombre de pluma fácil y de convicciones profundas, no se arredra por tal pequeñez. Si a él se le excomulga, no reconoce autoridad en los excomulgadores, y poco le falta para decir, como un Luis XIV del ultraísmo: «El Ultraísmo soy yo» ${ }^{57}$.

Pese a prescindir de la colaboración de Ernesto López-Parra, en Vltra resonarán en números sucesivos algunos ecos de la polémica. Los redactores de la revista parecen aprovechar sus polémicos entrefiletes para zaherir a sus detractores: «El ultraísmo lo es todo. Lo que está fuera de él no existe. No hay más que poetas ultraístas: los otros andan por ahí con su cadáver a cuestas». Esto se lee en el número 15 (30 de junio de 1921), en donde se inserta otra consigna que parece responder directamente al artículo publicado por López-Parra en La Tribuna: «¿Qué no hay poetas viejos y nuevos?¿Quién les ha dicho a ustedes eso? Se pueden hacer perfectas versificaciones a la manera clásica; pero eso no es la poesía ni es el ultraísmo». Por otra parte, Vltra utilizará otra táctica de corte totalitario para minusvalorar la figura de quien se ha decidido expulsar del grupo: silenciar su obra, incluso cuando ésta aparece en revistas hermanas de las que se da noticia. Es lo que ocurre en el último número de Vltra, en donde se reseña la aparición de una antología del ultraísmo que Tadeusz Peiper había publicado en la revista polaca Nowa $S z$ tuka. Los poemas traducidos al polaco serían obra de «Vicente Huidobro, J. Rivas Panedas, Guillermo de Torre y Humberto Rivas». Se omite de este modo a Ernesto López-Parra, que también participa en esa antología con el poema «Bordel», previamente aparecido en el número 6 de Vltra ${ }^{58}$.

El caso de López-Parra no fue, con todo, el único. Tal y como ha apuntado Rafael Osuna hubo algún otro arranque inquisitorial:

El ultraísmo de Madrid va a llegar ahora a otra de sus cimas inquisitoriales con motivo del estreno de Linterna Mágica, de Martínez Sierra, en cuya presentación había colaborado Barradas. ¿Barradas, sujeto de la Inquisición ultraísta? ¿Barradas va a correr la misma suerte que López-Parra? «La presencia de Barradas en el escenario del Eslava, lejos de ser un augurio optimista, es un escarnio y una curva perjudicial para la próxima y decisiva instauración de un arte nuevo, sin contacto ni parentesco con las gastadas modalidades anteriores (...)». Así de claro. La democracia no existe en este Parnaso, que más se asemeja a una dictadura poética en la que todos los vasallos tienen que escribir lo mismo; si se diseña un atrezzo, hay que diseñarlo para los portaliras ultraístas nada más. El Gran Inquisidor, Humberto Rivas, dixit. Pero Barradas no puede correr la misma suerte que

${ }^{57}$ S.f. «El excomulgado». $L a$ Voz, 18 de junio de 1921, p. 1. Sobre Díez-Canedo y su sección «La cena de las burlas» véase PÉREZ ZORRILLA, Elda. «E. Díez-Canedo y La cena de las burlas». Cauce, 2004, n. ${ }^{\circ}$ 27, pp. 319-340.

${ }^{58}$ Allí apareció con el título castellano de «Burdel», en compañía del poema «Verbena». Los dos agrupados bajo el común rótulo de «Poemas urbanos». 
López-Parra; Barradas es mucho Barradas. Por eso la portada es de él y también lo será un grabado del próximo número ${ }^{59}$.

El comité directivo de Vltra parece tomarse muy en serio su labor depuradora, y no deja pasar la menor oportunidad de recriminar a sus colaboradores cuando traspasan las que se consideran líneas rojas de la vanguardia. Tales ardores de ortodoxia serán paradójicamente purgados no mucho después en otras revistas auspiciadas por los oficiantes del Ultra. El grado de sectarismo al que se había llegado parece haber servido de vacuna para futuras empresas. Así ocurre con Horizonte, revista dirigida por Pedro Garfias que, amén del arte de vanguardia, abre sus páginas a los poetas mayores (Antonio Machado, Juan Ramón Jiménez) o al neopopularismo de Rafael Alberti o de Federico García Lorca (en la revista se publica su «Baladilla de los tres ríos»).

Nacerá también en 1925 la revista Plural, de significativo título, dirigida por César A. Comet, en cuyo «Propósito» inicial parece entonarse un mea culpa por los excesos rigoristas cometidos en el pasado, que fueron en detrimento del nacimiento de voces personales:

Ahora bien, si en el primer momento el nudo ceñía nuestras voluntades y unificaba nuestros espíritus en una cierta comunidad de ideas, o, más aún, una determinada actitud estética singularizada por un carácter sectario y un gesto polémico rebasador - ultraísmo- , hoy tal ingrediente cohesivo se halla reducido al afán de centralizar, de aunar varios esfuerzos, acaso disímiles exteriormente aunque unánimes y fraternos en su raíz. Con ellos queremos expresar que las páginas de Plural no tendrán deliberadamente un color tampoco unilateral: no serán al modo de una cándida pantalla sobre cuya nitidez se reflejen solamente determinados gestos y actitudes: no adquirirá la forma de un portavoz emisor de un acento único a cuya modulación hayan de conformarse todos los que a él se aproximen. El sectarismo, la heterodoxia y, en suma, el inevitable y magnífico timbre personal podrán estar - y ello es nuestro deseo- en algunos de sus colaboradores, mas sin llegar a constituir absorbente denominador común de la revista.

Plural —como insinúa su título- aspira más sobria y modestamente a recoger y proyectar las manifestaciones singulares de una pluralidad de espíritus jóvenes - no enlazados, en esta ocasión, repetimos, por un credo estético ortodoxo-, libres y rebasadores $(\ldots)^{60}$.

Por su parte, el otrora intransigente Humberto Rivas parece renovarse con aires más inclusivos en su revista de 1926 Sagitario, eso sí, poniendo como tope a las colaboraciones el estar animadas por un espíritu renovador:

Quizá nuestra revista no sea una revista para todo el mundo, aunque nosotros no nos proponemos excluir a nadie que quiera venir con nosotros. Insinuamos este temor o esta posibilidad ante el desdén manifiesto con que el gran público acoge invariablemente todo aquello que cae fuera de los límites de su predilección.

${ }^{59}$ OSUNA, Rafael, op.. cit., p. 199. La arremetida contra Rafael Barradas, firmada con las iniciales H. R., aparece en el número 21 de Vltra (1 de enero de 1922). Aunque, como apunta Rafael Osuna, en el número siguiente Barradas colabora con un grabado, su firma no aparece en los dos números siguientes, los últimos de Vltra.

${ }^{60}$ Citado por OSUNA, Rafael, op. cit., pp. 264-265. 


\begin{abstract}
Contaremos y estaremos siempre con las minorías aristocráticas — para nosotros no existe más aristocracia que la espiritual- que son, después de todo, y a despecho de las multitudes frívolas y superficiales, las que abren el surco de las civilizaciones. Esto no quiere decir que desdeñemos a la multitud, sino que preferimos esperar que venga ella aquí en lugar de ir nosotros a ella.

Revista del Siglo XX llamamos a esta nuestra revista y al llamarla así hemos querido dar a entender que en ella tendrán cabida todos los problemas y todas las inquietudes de la época en que vivimos. Hombres de nuestro tiempo, modernos ante todo - respetaremos lo que la tradición tenga de fundamental y de permanente, pero sin caer en las aberraciones clasicistas y casticistas que suelen ser la peor forma de la impotencia ${ }^{61}$.
\end{abstract}

Las revistas del 27 , que inmediatamente van a tomar el testigo y que van a oscurecer con pleno conocimiento de causa la labor renovadora acometida por sus coetáneos los ultraístas, no tendrán estos recelos anti-clasicistas que los poetas del Ultra heredan del futurismo. Esa falta de apriorismos y, sobre todo, la enorme valía de sus miembros hacen que el 27 oculte bajo una espesa capa de silencio el posible logro del ultraísmo, en cuyo afán también se habían involucrado Dámaso Alonso, Rafael Alberti, Vicente Aleixandre o Gerardo Diego. Los tres primeros ocultarán ese pasado, seguramente por considerar aquellos poemas primerizos como simples esbozos propios de poetas en sazón. Gerardo Diego mantendrá con orgullo a lo largo de su vida su militancia en la vanguardia, en especial dentro de la modalidad creacionista, lo cual no le impedirá proclamar, en un arranque de inmodestia, que el ultraísmo lo había inventado él ${ }^{62}$.

Lo cierto es que a la altura de junio de 1921, tal vez condicionado por el asunto de la expulsión de López-Parra, Gerardo Diego, como hemos visto, envía una carta a José Ortega y Gasset en la que parece tomar partido por el talaverano cuando apunta que el «poeta de hoy es compatible con todos y con todo. No le estorba el simbolismo ni el futurismo, ni aun el romanticismo». Esa amplitud de miras le había costado cara a López-Parra. Con ello, sin duda, el Ultra no castigaba un caso concreto y aislado, sino que pretendía deshacerse de algo que le era consustancial por hallarse inserto en su ADN: todos los poetas embarcados en la nueva escuela provenían del modernismo, y no era raro por ello que de vez en cuando se colaran en sus poemas ciertos dejes de la vieja escuela. López-Parra o Rafael Barradas serán de este modo los chivos expiatorios encargados de pagar unos pecados que en realidad eran gremiales. Poco después el Ultra será historia, y los nuevos aires mantendrán un diálogo mucho más amistoso y productivo con lo anterior, sin tantas prevenciones ni reservas infundadas.

Fecha de recepción: 20 de noviembre de 2007

Fecha de aceptación: 24 de junio de 2008

\footnotetext{
${ }^{61}$ Idem, pp. 275-276.

${ }^{62}$ DELGADO, Fernando G. «Entrevista. Gerardo Diego a las puertas de los ochenta años». Ínsula, mayo de 1976, n. ${ }^{\circ} 354$, p. 12.
} 